\title{
Isolation and Characterization of an Anaerobic, Cellulolytic Bacterium, Clostridium papyrosolvens sp. nov.
}

\author{
ROBERT H. MADDEN, $\dagger$ MICHELE J. BRYDER, AND NIGEL J. POOLE \\ Department of Microbiology, Marischal College, Aberdeen University, Aberdeen, Scotland
}

\begin{abstract}
Clostridium papyrosolvens, a new species of cellulolytic, sporeforming, anaerobic bacteria, is described. The colonies produced by these bacteria in cellulose agar roll-tubes were spherical, translucent, unpigmented, and of granular appearance. Single cells of the bacterium were straight rods, 0.5 to $0.8 \mu \mathrm{m}$ by 2 to $5 \mu \mathrm{m}$, peritrichous, and motile. Spherical terminal spores 1 to $1.2 \mu \mathrm{m}$ in diameter were formed. Fermentation products from cellulose included hydrogen, carbon dioxide, ethanol, acetate, and lactate. The deoxyribonucleic acid base composition of the type strain of $C$. papyrosolvens, NCIB 11394, is $30 \mathrm{~mol} \%$ guanine plus cytosine. The specific epithet papyrosolvens reflects the ability of the organism to ferment filter paper.
\end{abstract}

The Microbiology Department of Aberdeen University has conducted studies on the microbial ecology of the estuarine sediments of the River Don, Aberdeenshire, Scotland, for several years $(9,11)$. Part of these studies concentrated on the population of cellulolytic bacteria which was maintained by the input of paper-mill effluent.

During studies on the organisms comprising the community present in the anoxic sediments which mineralized the cellulose, a pure culture of a strictly anaerobic, cellulolytic bacterium was isolated. This report describes the isolation and characterization of this organism.

\section{MATERIALS AND METHODS}

Media. The solid medium used in this study consisted of: $\mathrm{NH}_{4} \mathrm{Cl}, 2.0 \mathrm{~g}$; yeast extract, $1.2 \mathrm{~g}$; agar no. 3 (Oxoid), $20.0 \mathrm{~g} ; \mathrm{K}_{2} \mathrm{HPO}_{4}, 1.65 \mathrm{~g}$; cysteine hydrochloride, $0.5 \mathrm{~g}$; resazurin solution $(0.1 \%$, wt $/ \mathrm{vol}), 1 \mathrm{ml}$; filtered seawater, $200 \mathrm{ml}$; mineral solution, $150 \mathrm{ml}$; cellulose suspension, $200 \mathrm{ml}$; and distilled water to 1 liter. The $\mathrm{pH}$ was adjusted to 7.2 with $5 \mathrm{M} \mathrm{NaOH}$.

The cellulose suspension used was $4 \%(\mathrm{wt} / \mathrm{vol})$ Whatman CF11 cellulose powder, ball-milled for $72 \mathrm{~h}$.

The mineral solution consisted of: $\left(\mathrm{NH}_{4}\right)_{2} \mathrm{SO}_{4}, 6.0$ $\mathrm{g} ; \mathrm{NaCl}, 6.0 \mathrm{~g} ; \mathrm{MgSO}_{4}, 0.6 \mathrm{~g} ; \mathrm{CaCl}_{2}, 0.6 \mathrm{~g}$; and distilled water to 1 liter.

The liquid medium used was similar to the solid medium except that it lacked agar and the cellulose suspension and had lower concentrations of $\mathrm{NH}_{4} \mathrm{Cl}$ and yeast extract (1.0 and $0.6 \mathrm{~g} /$ liter, respectively). Cellulose was provided as a strip $(9.0 \mathrm{by} 1.0 \mathrm{~cm})$ of Whatman no. 1 filter paper in each tube.

The solid medium was dispensed in tubes in $4.5-\mathrm{ml}$

$\dagger$ Present address: Agricultural and Food Science Research Centre, Belfast BT9 5PX, Northern Ireland. volumes, and the liquid medium was dispensed in 10ml volumes.

When carbon sources other than cellulose were used, the material was dissolved in the liquid medium $(3 \%, \mathrm{wt} / \mathrm{vol})$ which was then boiled to remove oxygen. The medium was cooled under nitrogen, and $2-\mathrm{ml}$ volumes were added to previously autoclaved $\left(121^{\circ} \mathrm{C}\right.$ for $15 \mathrm{~min})$ tubes of liquid medium $(10 \mathrm{ml})$ by filter sterilization.

Blanks for serial dilutions were prepared from $2 \%$ (wt/vol) $\mathrm{NaCl}$ containing $0.5 \mathrm{~g}$ of cysteine hydrochloride and $1 \mathrm{mg}$ of resazurin per liter. The diluent was adjusted to $\mathrm{pH} 7.0$ with $0.5 \mathrm{M} \mathrm{NaOH}$ prior to being dispensed in 9-ml volumes into McCartney bottles.

Anaerobic culture methods. The anaerobic techniques of Hungate (7) were used throughout this study. Standard test tubes $(19$ by $150 \mathrm{~mm}$, Corning Glass Works) sealed with Suba Seal no. 29 closures (William Freeman Ltd., Barnsley, Great Britain) were used as culture tubes. Hungate roll tubes of solid media were used for the identification and selection of cellulolytic bacteria. Routine incubations were performed at $25^{\circ} \mathrm{C}$. Oxygen-free nitrogen was used as the atmosphere.

Isolation procedures. Anaerobic mud was obtained from intertidal mud banks of the River Don, Aberdeenshire, Scotland, by means of the sampling system described by Parkes et al. (11). Sediment from a depth of $5 \mathrm{~cm}$ was diluted $100-$ fold, and $0.2-\mathrm{ml}$ samples were inoculated into triplicate tubes of liquid medium. After 10 days, $0.2-\mathrm{ml}$ samples were subcultured into fresh liquid medium; this procedure was repeated twice. The final series of tubes was incubated for 2 months.

Medium from the final cultures was then serially diluted into roll tubes which were heat shocked at $70^{\circ} \mathrm{C}$ for $15 \mathrm{~min}$, prior to rolling, to induce spore germination. After 3 weeks of incubation, cellulolytic colonies were transferred to cellobiose medium by means of a bent Pasteur pipette (7). After 5 days, subcultures (0.2$\mathrm{ml}$ inocula) were made in fresh cellobiose medium. The subcultures were again incubated for 5 days and were then serially diluted into roll tubes. Subcultures 
(0.2-ml inocula) in liquid medium were also made

Culture purity was then assessed by microscopic examination and by examination of roll tubes for noncellulolytic colonies.

Morphology. Living and stained cells were examined by light microscopy. Flagella were examined with a Seimens Elmiskop 102 transmission electron microscope. A 2-day-old culture grown on cellobiose was harvested by centrifugation for $20 \mathrm{~min}$ at $1,500 \times g$ (average) and suspended in distilled water and centrifuged as before. This washing procedure was repeated twice. A drop of the suspension of washed cells was placed on a Formvar-coated copper grid and was shadowed with gold-palladium (40:60) at an angle of $20^{\circ} \mathrm{C}$.

Biochemical reactions. Biochemical characteristics were studied by the methods described by Holdeman et al. (4).

DNA base composition. Deoxyribonucleic acid (DNA) was isolated by the method of $\mathrm{Ng}$ et al. (10) The guanine-plus-cystosine content of the DNA was determined by thermal denaturation (3). Escherichia coli K-12 DNA (Sigma Chemical Co.) was used as a standard.

Fermentation end-product analyses. To detect volatile fatty acids and alcohols as end products of fermentation, samples of media $(2.5 \mathrm{ml})$ were deproteinized by the addition of $0.1 \mathrm{ml}$ of $\mathrm{ZnCl}_{2}(10 \%$, wt $/ \mathrm{vol})$ and were centrifuged at $12,000 \times g$ (average) for $15 \mathrm{~min}$.

Five microliters of supernatant was injected into a gas chromatograph fitted with a Chromosorb 101 (80/ $100 \mathrm{mesh}$ ) column, $1.5 \mathrm{~m}$ by $3.18 \mathrm{~mm}$ (inside diameter). The chromatograph was fitted with a flame ionization detector, and the following conditions were selected for the analysis: column temperature, $110^{\circ} \mathrm{C}$ on injection increasing by $15 \mathrm{C}$ degrees/min to $180^{\circ} \mathrm{C}$ where it was held until all of the volatile fatty acids had eluted; carrier gas, 1 bar of nitrogen at the column head; injector temperature, $180^{\circ} \mathrm{C}$; detector temperature, $240^{\circ} \mathrm{C}$; hydrogen flow rate, $25 \mathrm{~cm}^{3} / \mathrm{min}$; and air flow rate, $400 \mathrm{~cm}^{3} / \mathrm{min}$.

Gases were analyzed by removing a sample $(0.5 \mathrm{ml})$ from the headspace of a culture tube by means of a 1 $\mathrm{ml}$ syringe and injecting the sample into a gas chromatography apparatus fitted with a silica gel $(80 / 100$ mesh) column, $1.5 \mathrm{~m}$ by $3.18 \mathrm{~mm}$ (inside diameter) The effluent from the silica gel column was fed into a molecular sieve 5A ( $40 / 60$ mesh) column, $1.5 \mathrm{~m}$ by 3.18 $\mathrm{mm}$ (inside diameter). The column temperature was $80^{\circ} \mathrm{C}$, and the carrier gas was argon. The injection temperature was $150^{\circ} \mathrm{C}$, and the detector temperature was $160^{\circ} \mathrm{C}$. Effluent gases were detected by thermal conducter with a filament current of $100 \mathrm{~mA}$.

Growth rate and temperature for optimal growth. For growth-rate determinations, $100 \mathrm{ml}$ of liquid medium plus 10 strips $(4.5$ by $1 \mathrm{~cm}$ ) of Whatman no. 1 filter paper were placed in a $250-\mathrm{ml}$ spherical flask and sealed with a butyl rubber bung. The flask was inoculated with $10 \mathrm{ml}$ of medium from a 5-day-old culture grown on filter paper. The flask was incubated at $28^{\circ} \mathrm{C}$ and sampled at 12 -h intervals. Samples $(0.5 \mathrm{ml})$ were obtained by piercing the bung with a syringe and needle. The $\mathrm{pH}$ 's, at $25^{\circ} \mathrm{C}$, of the samples were noted before the quantities of acetate and ethanol were determined.

The temperature for optimal growth was determined by inoculating a batch of 18 tubes of liquid medium with $0.2 \mathrm{ml}$ of a 5-day-old culture grown in a similar medium. Triplicate tubes were then incubated for 14 days at each temperature studied. The $\mathrm{pH}$ of the medium was then measured at $25^{\circ} \mathrm{C}$, and the quantity of cell protein produced was determined

Cell protein was estimated by centrifuging the entire contents of a tube at $10,000 \times g$ (average) for $15 \mathrm{~min}$. The supernatant was discarded, and the pelleted cells were suspended in $10 \mathrm{ml}$ of $2 \%$ (wt/vol) $\mathrm{NaCl}$. The washed cells were again harvested by centrifugation at $10,000 \times g$ (average) for $15 \mathrm{~min}$. The supernatant was discarded, and the cells in the pellet were lysed by suspending them in $0.2 \mathrm{M} \mathrm{NaOH}(2 \mathrm{ml})$. The protein in the suspension was determined by the method of Lowry et al. (8). Before measurement of the optical density, the medium was clarified by centrifugation at $5,000 \times g$ (average) for $5 \mathrm{~min}$ to pellet residual cellulose. Bovine serum albumin (Sigma Chemical Co.) was used as a standard.

Lactate determination. Lactate was determined enzymatically by means of a lactate dehydrogenasebased kit (Boehringer Mannheim GmbH, Biochemica, Mannheim, West Germany).

\section{RESULTS}

The enrichment and selection procedures used resulted in the isolation of a pure culture of an obligately anaerobic, cellulolytic organism. When heat-shocked spore inocula were used, visible colonies were produced in roll tubes in 7 to 10 days, and after 3 weeks, the colonies were 1 to $2 \mathrm{~mm}$ in diameter, unpigmented, and granular in appearance. Further incubation resulted in a darkening of the colonies to a pale-tan color. Clear zones, showing cellulose hydrolysis, were generally 1 to $2 \mathrm{~cm}$ in diameter in high-dilution tubes after an incubation of 3 weeks, but they continued to extend, and zones larger than $3 \mathrm{~cm}$ in diameter were not uncommon after prolonged incubation ( 1 to 2 months).

During this study it was noted that spores inoculated into roll tubes did not germinate unless a thermal shock was applied. One batch of four roll tubes was incubated for 1 year, and no cellulolytic colonies were visible. However, after a heat shock, cellulolytic colonies appeared 10 to 14 days later.

The isolate consisted of straight rods, 0.5 to $0.8 \mu \mathrm{m}$ by 2.0 to $5.0 \mu \mathrm{m}$, with terminal spores 1 to $1.2 \mu \mathrm{m}$ in diameter. It was motile and peritrichous (Fig. 1).

Growth in nutrient broth without fermentable carbohydrate was slight; with fermentable carbohydrate, growth was moderate. Milk was unchanged.

Table 1 lists the biochemical characteristics of the isolate.

The fermentation of cellulose resulted in the production of acetate, ethanol, lactate, carbon dioxide, and hydrogen. The mean generation time of a cellulose-grown culture incubated at $28^{\circ} \mathrm{C}$ was estimated as $20 \mathrm{~h}$, based on the total 

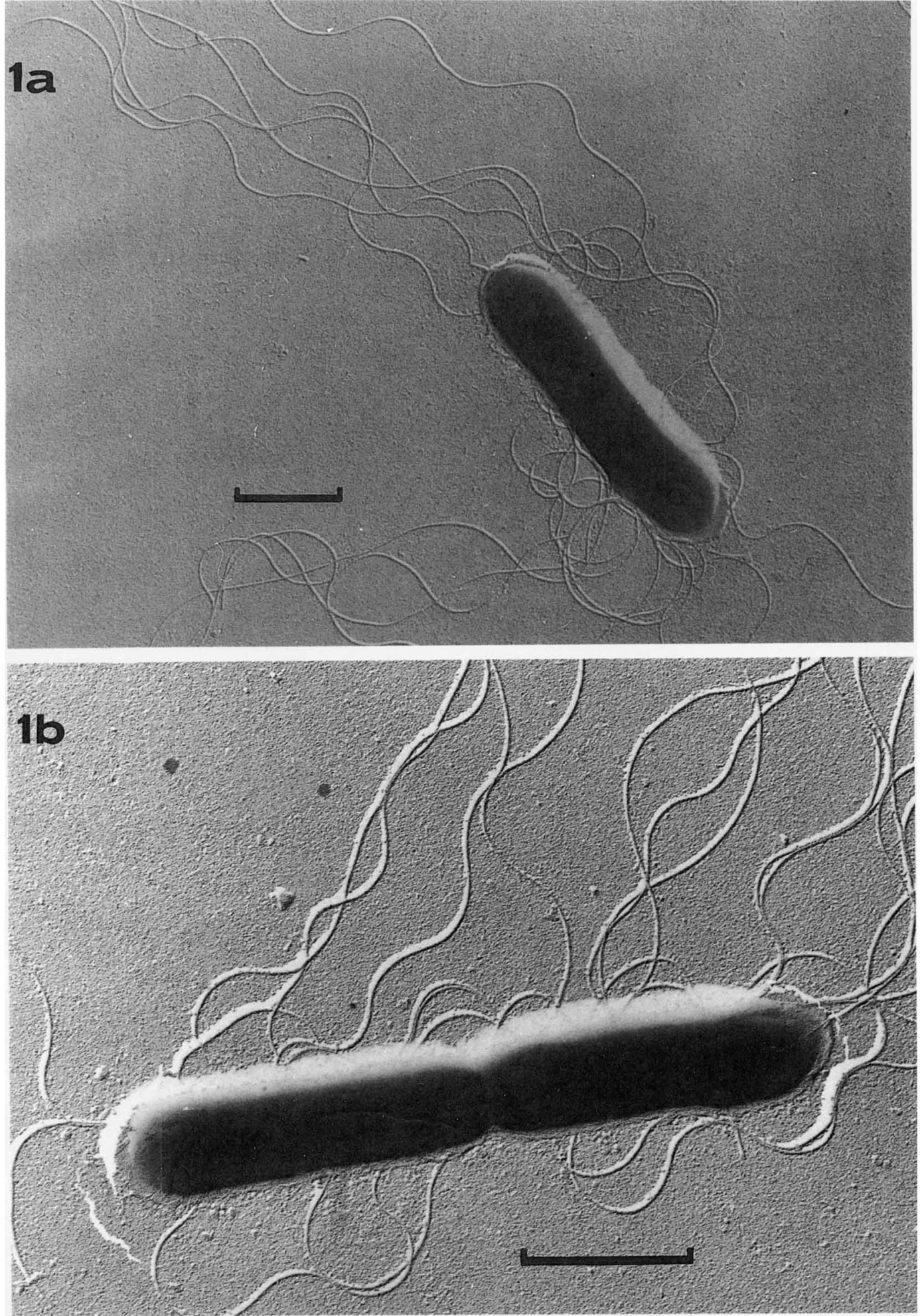

FIG. 1. Electron micrographs depicting cell morphology and flagella. (A) Single peritrichous cell. The bar represents $1 \mu \mathrm{m}(\times 15,000)$. (B) Dividing cell. The bar represents $1 \mu \mathrm{m}(\times 24,000)$. 
TABLE 1. Biochemical characteristics of the new isolate

Assays giving negative results:

Acetylmethylcarbinol production

Catalase production

Lecithinase production

Urease production

Carbohydrates not fermented:

\begin{tabular}{|c|c|c|c|c|}
\hline Adonitol & Amygdalin & Chitin & Dulcitol & Erythritol \\
\hline Glycogen & Inositol & Inulin & Lactose & Mannitol \\
\hline Maltose & Mannose & Melezitose & Melibiose & Raffinose \\
\hline Rhamnose & Salicin & Sorbitol & Sorbose & Sucrose \\
\hline \multicolumn{5}{|l|}{ Trehalose } \\
\hline \multicolumn{5}{|c|}{ Carbohydrates fermented: } \\
\hline Arabinose & Cellobiose & Cellulose & Esculin & Fructose \\
\hline Galactose & Glucose & Glycerol & Ribose & Xylose \\
\hline
\end{tabular}

concentration of ethanol and acetate produced (9).

The temperature range for optimal growth on cellulose was 25 to $30^{\circ} \mathrm{C}$. Growth occurred at $15^{\circ} \mathrm{C}$. Slight growth was noted at $45^{\circ} \mathrm{C}$.

During investigations to determine the temperature for optimal growth, it was discovered that spore inocula did not result in viable cultures at $37^{\circ} \mathrm{C}$ or above, whereas vegetative cells did grow at these temperatures. Subsequently, in all experiments involving growth vegetative cells were used as inocula.

The guanine-plus-cytosine content of the DNA of the isolate was $30 \mathrm{~mol} \%$.

Vegetative cells were readily decolorized and hence were gram negative. However, transmission electron microscopy of sections revealed a cell wall structure typical of gram-positive organisms.

\section{DISCUSSION}

On the basis of the identification scheme in the 8th edition of Bergey's Manual (1), the isolate was identified as a member of group III of the genus Clostridium. The 1980 Approved Lists of Bacterial Names (12) were used to exclude comparison of the isolate with species whose names had no standing in nomenclature. Subsequent comparison of the isolate with published descriptions of all group III species $(4,13)$ revealed that the isolate was most similar to Clostridium cellobioparum, the only member of this group currently recognized as cellulolytic.

Comparison of the new isolate with the original description of $C$. cellobioparum (5) showed significant differences in colony morphology. Young colonies of $C$. cellobioparum were disk shaped and compact in glucose shakes but were irregular in cellulose agar (5). The new isolate produced regular spherical colonies in similar media. Cell morphology was similar to that of $C$.
Blood hemolysis

Gelatin liquefaction

Lipase production
Casein hydrolysis $\mathrm{H}_{2} \mathrm{~S}$ production Nitrate reduction cellobioparum, as originally described. However, a later description noted that $C$. cellobioparum can produce oval spores (13), and these were never seen in cultures of the new isolate. Descriptions of the biochemical characteristics of $C$. cellobioparum differ slightly, but on the basis of these, $C$. cellobioparum can be readily distinguished from the new isolate. The principal differences are shown in Table 2. The growth of the new isolate at $15^{\circ} \mathrm{C}$ contrasts with the inhibition of growth of C. cellobioparum at $25^{\circ} \mathrm{C} \mathrm{(13),}$ although it should be noted that a temperature of $18^{\circ} \mathrm{C}$ was originally recorded for the latter (5). It is also significant that $C$. cellobioparum was isolated by means of enrichment and selection procedures performed at $38^{\circ} \mathrm{C}$ (5). Such procedures favor the isolation of sporeforming organisms (6), but since the spores of the new isolate do not produce viable cultures at this temperature, the organism would be actively selected against. Finally, $C$. cellobioparum has been reported to produce butyrate when fermenting glucose (2), but butyrate was never detected in cultures of the new isolate during fermentation of glucose, cellobiose, cellulose, or esculin.

In summary, a cellulolytic organism was isolated, and its initial characterization showed it to be a member of group III of the genus Clostridium. A comparison of the isolate with the most similar organisms of this group showed significant differences, and the isolate is therefore proposed as a new species, Clostridium papyrosolvens (L. noun papyrus paper; L. verb solvere to dissolve; M.L. adj. papyrosolvens paperdissolving; intended to reflect the organism's ready fermentation of filter paper).

Clostridium papyrosolvens $\mathrm{sp}$. nov. Straight rods, 0.5 to $0.8 \mu \mathrm{m}$ by 2.0 to $5.0 \mu \mathrm{m}$. Motile and peritrichous. Endospores are spherical and terminal. Gram negative.

Deep colonies in cellulose agar are 1 to $2 \mathrm{~mm}$ in diameter, granular, and unpigmented. 
TABLE 2. Principal differences between the new isolate and C. cellobioparum as described by Hungate (5) and in Bergey's Manual (13) and the Anaerobe Laboratory Manual (4) ${ }^{a}$

\begin{tabular}{|c|c|c|c|c|}
\hline \multirow[b]{2}{*}{ Determination } & \multicolumn{3}{|c|}{ C. cellobiopartm } & \multirow[b]{2}{*}{$\begin{array}{l}\text { New } \\
\text { isolate }\end{array}$} \\
\hline & Hungate & $\begin{array}{c}\text { Bergey's } \\
\text { Manual }\end{array}$ & $\begin{array}{c}\text { Anaerobe } \\
\text { Laboratory } \\
\text { Manual }\end{array}$ & \\
\hline \multicolumn{5}{|l|}{ Carbohydrate fermentation } \\
\hline Dulcitol & NR & + & + & - \\
\hline Glycerol & - & W & W & + \\
\hline Lactose & $\mathrm{S}$ & W & W & - \\
\hline Maltose & + & + & + & - \\
\hline Mannitol & NR & W & W & - \\
\hline Mannose & + & + & + & - \\
\hline Melibiose & + & + & + & - \\
\hline Raffinose & $\mathrm{S}$ & + & W & - \\
\hline Sorbitol & NR & + & W & - \\
\hline Mol\% guanine plus cytosine & NR & 25 & 28 & 30 \\
\hline
\end{tabular}

${ }^{a}$ NR, not determined; W, weakly fermented; S, occasionally and slowly fermented.

Slight growth occurs in nutrient broth without fermentable carbohydrate; moderate growth occurs in the presence of a fermentable carbohy drate.

Ferments cellulose. Fermentation products include ethanol, acetate, lactate, hydrogen, and carbon dioxide.

Acetylmethylcarbinol is not formed.

Milk is unchanged.

Found in an estuarine anaerobic sediment.

The guanine-plus-cytosine content of the DNA is $30 \mathrm{~mol} \%$.

Type strain: National Collection of Industrial Bacteria strain NCIB 11394. Since the species is based on a single strain, the type strain, the description of the type strain is the same as that given above for the species.

\section{ACKNOWLEDGMENTS}

We thank A. MacKenzie and G. Hobbs for advice and assistance during this work. S. J. Joles provided essential technical assistance in obtaining sediment samples, and W. Hodgkiss produced the electron micrographs.

\section{REPRINT REQUESTS}

Address reprint requests to: Dr. Robert H. Madden, Agricultural and Food Science Research Center, Newforge Lane, Belfast BT9 5PX, Northern Ireland.

\section{LITERATURE CITED}

1. Buchanan, R. E., and N. E. Gibbons (ed.). 1974. Bergey's manual of determinative bacteriology, 8th ed. The Williams \& Wilkins Co., Baltimore.

2. Chung, K. 1976. Inhibitory effects of $\mathbf{H}_{2}$ on growth of Clostridium cellobioparum. Appl. Environ. Microbiol. 31:342-348.
3. De Ley, J. 1969. Reexamination of the association between melting point bouyant density, and chemical base composition of deoxyribonucleic acid. J. Bacteriol. 101:738-759.

4. Holdeman, L. V., E. P. Cato, and W. E. C. Moore (ed.). 1977. Anaerobe laboratory manual, 4th ed. Anaerobe Laboratory, Virginia Polytechnic Institute and State University, Blacksburg.

5. Hungate, R. E. 1944. The culture and physiology of an anaerobic cellulose-digesting bacterium. J. Bacteriol. 48:499-513.

6. Hungate, R. E. 1950. The anaerobic mesophilic cellulolytic bacteria. Bacteriol. Rev. 14:1-49.

7. Hungate, R. E. 1969. A roll tube method for cultivation of strict anaerobes, p. 117-132. In J. R. Norris and D. W. Ribbons (ed.), Methods in microbiology, vol. 3b. Academic Press, London.

8. Lowry, O. H., N. J. Rosebrough, A. L. Farr, and R. J. Randall. 1951. Protein measurement with the Folin phenol reagent. J. Biol. Chem. 193:265-275.

9. Madden, R. H., M. J. Bryder, and N. J. Poole. 1980. The cellulolytic community of an anaerobic estuarine sediment, p. 366-371. In P. Chartier and D. O. Hall (ed.), Proceedings of the international conference on energy from biomass. Applied Science, London.

10. Ng, T. K., P. J. Weimer, and J. G. Zeikus. 1977. Cellulolytic and physiological properties of Clostridium thermocellum. Arch. Microbiol. 114:1-7.

11. Parkes, R. J. P., M. J. Bryder, R. H. Madden, and N. J. Poole. 1979. Techniques for investigating the role of anaerobic bacteria in estuarine sediments, p. 107-118. In Methodology for biomass determinations and microbial activity in estuarine sediments. American Society For Testing and Materials, Philadelphia.

12. Skerman, V. B. D., V. McGowan, and P. H. A. Sneath (ed.). 1980. Approved lists of bacterial names. Int. J. Syst. Bacteriol, 30:225-420.

13. Smith L. DS., and G. Hobbs. 1974. Genus III. Clostridium, p. 551-572. In R. E. Buchanan, and N. E. Gibbons (ed.), Bergey's manual of determinative bacteriology, 8 th ed. The Williams \& Wilkins Co., Baltimore. 